\title{
IMPORTANCE OF HUMIC SUBSTANCES FOR STABILIZING SOIL AGGREGATES AND CENTRAL REACTIONS EXPLANATION IN SOIL: A REVIEW
}

\author{
${ }^{*}$ Atheer A. Abbood ${ }^{1}$
}

Abdul-Sahib T. Al-Madhhachi ${ }^{1}$

1) Environmental Engineering Department, College of Engineering, Mustansiriyah University, Baghdad, Iraq

\begin{abstract}
Humic substances have an essential function in soil fertility and are viewed as being of prime importance for soil aggregation stability. Humic substances as part of humus-soil organic matter are chemicals generated from the biomolecules physically, chemical and microbiologically (humifying). It is essential since it is the most pervasive biological material source, which nature knows. Roughly 80 percent of total carbon is produced with terrestrial humic compounds and 60 percent of the water dissolved carbon. During the last three decades there have been challenges in two major approaches, the concept of soil humic substances. Much of the organic aromatic soil originates from the carbon that is frequently known as black carbon (black carbon). However, the detection of benzene polycarboxylic acid markers and the UV technique in soil with two commonly used methods is not trustworthy. Polymerisation of phenolic compounds produced from the breakdown and synthesis of lignin microorganisms may result in a wide number of humic chemicals and components including organic molecules and inorganic molecules. The addition of e.g., triazines or tensile compounds that cause to bound residues in the humic matrix demonstrates that humic substances are crucial for clarifying critical soil processes. Plant nutrients, comprising $\mathrm{p}$, fe and $\mathrm{cu}$, are available in soil this is equally essential to understand and can directly influence the growth of higher plants in the soil.
\end{abstract}

Keywords: Humic substances, Nitrogen Management, black carbon overestimation, Stabilizing Soil.

\section{Introduction}

Soil organic matter (SOM) is one of the contributing factors for stabilizing soil aggregates, supplying nutrients and maintaining soil microbiology [1]. The dynamics of SOM are motivated by the addition of organic compounds that are transformed as time passes, a combination of chemical, and biological factors have a role [2], [3]. Such transformations When organic matter decomposes, the size of the molecules, chemical composition, structure and functional groups change, along with the polyelectrolytic properties of the supplementary material change [4],[5],[6] In chemical words, three fractions of humic substances (HS) are composed of organic matter: humic acid, fulvic acid and humin [7]. Each one of these compounds has a specific purpose in the soil: fulvic and humic acid, for example, has a role in the transport of cations between organic mineral complexes exchanged and also affect the organic origin cation exchange capacity (CEC) [8],[9],[10]. Between 80 and 90 percent of all SOM eventually type humic substances. Heterogeneous molecular compounds containing various functional groups are

*Corresponding Author: atheeralzobaie@gmail.com 
composed [11]. They are dark in color, hydrophilic and stable with no specified properties, and their components can vary as follows: 40 to 60 percent $\mathrm{C}$; 30 to 50 percent $\mathrm{O}$; 0 to 4 percent $\mathrm{N} ; 2$ to 4 percent $\mathrm{H}$; 0 to 2 percent $\mathrm{S}$ [12]. To produce complexes with varying degrees of stability and structural features, humic substances interact with ions [13]. The soil managing stage in agricultural areas can be indicated by all these features. In order to circuitously assess soil management efficiency based on the degree of SOM humification, some authors have used humic substances [14], [15]. Depending on the current structures, SOM from organic residues increases the carbon content, usually with carboxyl and aromatic bonds, and there is a decrease in carbon associated with polysaccharides [2],[16]. Humic fractions therefore aim to enhance particle cohesion and aggregate stability are linked to aggregate particle size dispersion and preservation of soil carbon [1],[6]. It can give valuable info on how to enhance soil quality by analyzing the spectral characteristics of different fractions of OM [17], [18]. The use of species diversity in agricultural management substantially increases the quality of organic matter, thereby effectively influencing the relation between soil aggregates. As a result, chemical composition of the soil changes, and as part of soil quality, humic and fulvic acids increase [19].

Improving the soil structure is one choice for mitigating the effects of erosion. This can be done using Natural aggregates and inorganic ones. This technology changes the soil's physical properties, such as porosity, Structural stability, infiltration and other factors that lead to higher water absorption in the soil Reducing surface runoff and preventing soil particle erosion ([20],[24]Liquid humus is an object that offers the same advantages as solid organic aggregates and can be spread Via the Method of Irrigation [5], [25]. The humus is mostly made up of humic humus, Fulvic acids (HFA), which make up between 60 and $80 \%$ of the soil's organic matter [26]. No difference was observed in the consistency of the aggregates after sludge-formed humus was added to the aggregates. Comparison of leonardite-based industrial humus [27]. Also, this researcher found an Optimum $21 \mathrm{t}$ ha-1 HFA dose. The effect of higher doses or the effect of mixing liquid humus with liquid humus, however, is any other inorganic aggregates have not been tested to enhance soil aggregation. The main goals of this research are The main aggregation formation and stabilization procedures and agents examine the main methodologies used for the determination of aggregate stability. The importance of considering the method characteristics because the methodology affects the results of stability and the opportunity for an estimate of soil erodibility using aggregate stability data is also analyzed.

\section{Soil Stabilization Methods}

Soil stabilisation is a general term for any method of changing a natural soil to meet an engineering purpose physique, chemical, biological, or combined [28].

There are four Types of Soil Stabilization Techniques:

\section{Mechanical:}

Mechanical in nature are the oldest forms of soil stabilisation. In order to influence its gradation, strength and other characteristics, mechanical solution involves changing of the soil's property. One of the major types of soil stabilization is dynamic compaction and vibrio compaction Compaction is widely used in ground stabilization and uses mechanical means to expel air vacuums within the soil mass to allow the ground to carry load without further compression [58].

\section{Chemical:}


Chemical solutions are another important type of soil stabilization. Solutions for chemicals. All these techniques are based on the addition of an additional material to the soil that interacts and modifies its characteristics physically. There are different types of soil stabilisation that use cement, lime, bitumen, ash and ovine dust based on a variety of chemical additives. In nature both cemented and pozzolan reactions are predominantly the traditional chemical stabilisators, for example, are calcium based, include lime, cement, bitumen and fly ash. [29].

\section{Polymer/Alternative:}

In the last decades only, the technology has opened new kinds of soil stabilisation for companies to explore. Both types of soil stabilisation have been around for hundreds, if not more, of years. Polymer based in the nature is the majority of the newer foundations and techniques developed so far, Polymers are essentially a glue in which the polymer binds the soil particles together in case it is used for soil stabilisation. The main ones are biopolymers and synthetic polymers, although there are many different polymers used for soil stabilization. It is important to note that each polymer has different qualities and is often more ecologically friendly than conventional measures for the stabilisation of the soil [113].

\section{Biological:}

In the case of organisms which take any environmental role, such as changes in fertility, stability, or soil structure, most scientists call a soil-cross "biotic." The use with algae and cyanobacteria for the matrix of biocrusts, for use in the upper millimeter area, was taken as nontoxic and environmentally friendly materials for soil stabilization. They are important for the first aggregation of soil particles that results in improved soil stability. Scientists are increasingly recognizing the role of biology in the formation and stability of soil structures, and the interest in managing soil biota is increasing in developing desired soil structure and minimizing the use of chemical stabilization the purpose is mainly the control of erosion through afforestation or planting. [30].

\section{3-Humic_Substances}

Up to 80 percent of organic matter of soil is constituted by humic substances [31]. The most common components of humic substances include carbon, oxygen, hydrogen, nitrogen, and sulfur [32]. The classifications of humics, Fulvic Acid, Humic Acid and Humin, are determined by the solubility in the following, as shown in "Fig. 1" [32]. The sodium hydroxide is soluble in humic acids and fulvic acids, but not humin [31]. Humic substance blends are then treated with acid after solubilization in sodium hydroxide that solubilizes the fulvic acid section and precipitates the humic acid portion [31]

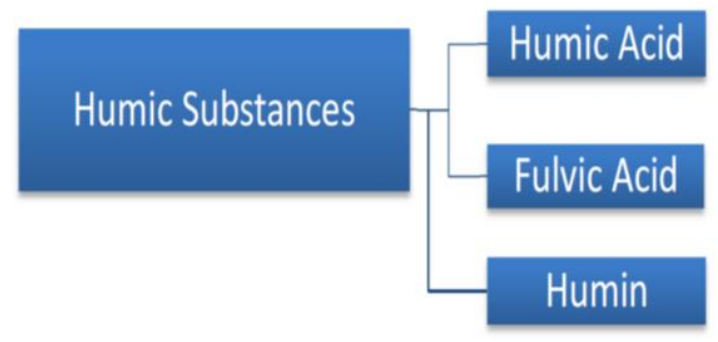

Figure1. Humic Substance Classification

The most common natural organic molecules on earth are the humic acids, which are frequently referred to as the "greatest vital component of a good fertile soil [32], [33]. In alkaline conditions, Humic acids are water soluble, but not acidic [32]. Approximately 35 percent of the varied structure of humic acid consists of carbon rings and the remainder of it consists of carbon chains. [32]. Humic acids are characteristically composed of 53.8- $58.7 \%$ carbon, $\quad 32.8-38.3 \%$ oxygen, $3.2-6.2 \%$ hydrogen, $0.8-4.3 \%$ nitrogen and $0.1-1.5 \%$ sulfur [34]. Fulvic acids are water soluble under 
acidic, neutral and alkaline conditions [32]. Fulvic acids have a cation exchange capacity that is more than twice as great as that of humic acids [32]. Fulvic acids are very small, which allows them to enter plant roots, stems and leaves with more ease than humic acids or humins [32]. Fulvic acids are often included in foliar plant applications, as they are "the most effective carbon containing chelating compounds known" [32].

The humin portion of humic substances is not soluble regardless of solution $\mathrm{pH}$ [32]. Humin has the greatest molecular weight of any humic substance and is extremely resistant to degradation [32]. The presence of humin in the soil improves the soil's water holding capacity, structure, and fertility, among other functions [32]. Composts, charcoal and peat are derived from commercially available Humic substances [35]. They are in liquid and granular forms. The soil or the leaves of the plant are treated with fluid humic substances [35]. The dirt is spread or mixed into the ground using granular humic materials [35]. The recommended liquid application rates are $0.4-12 \mathrm{~L}$ per acre [35]. The proposed ranges from 22 to 357 pounds per acre for granular application [35].

\subsection{Humic Substances As a Concept in Soil Organic Matter Research.}

According to Achard, de Saissur and Sprengel's work, in the early nineteenth century [5]. In the latter part of the 20th century, the idea of soil humic compounds was completely developed. The fundamental assumption inside concept of "humic substances" that breakdown crops of plant debris and microbial communities employed in part to build new compounds via biochemical, chemical and biological pathways. The humic substances are these compounds. Schnitzer and Ziechmann [36-38] provided detailed descriptions of the molecular and biological processes involved, which were also summarized [5]. The reaction principles describe the production of humic compounds in phenolic compounds as polymerisation processes. Phenols are first derived through lignin degradation and subsequent reactions to phenylpropene units, [5], [37], and also from the microbial production of phenolic compounds, as described, for example, by [39]. The rings containing combined pi-electros, which delocalize electrons and produce radicals, are the aromatic compounds such as Polyphenols (molecules with free, unpaired electrons). Within the polymerization reaction products, the various mesomer forms of radicals of hydroquinone are used to create separate irregular bonding types, C-C- and C-O-C. Hydroquinone reacts in alkaline solution by forming aromatic and brown high molecular weight reaction products. Catechol, or dihydroxyphenol, likewise generates such dark products for alkaline solution and high molecular reaction weight products, but mdihydroxyphenol in alkaline solution is not polymers. Flaig [37] showed various mechanisms by which lignin degradation might lead to polymerisation of phenylpropene units. They have shown that phenols do not polymerize to humic-like compounds if $\mathrm{p}$ position $\mathrm{OH}$ - groups were methylation inside a phenol ring. This is also consistent with the humic formation concept presented [38],[40], which has shown that additional or fewer unchanged lignin interacts with humic pyrogallol polymers and has been chemically integrated into the humic framework. Haider [41]. It has also revealed that some fungal melanins, as assessed by pyrolysis mass spectrometry, are comparable to soil humic acids. The incorporation by $-\mathrm{C}=\mathrm{NC}-$ or $-\mathrm{C}-\mathrm{N}-$ $\mathrm{C}$ - bonds of nitrogen $(\mathrm{N})$ into humic polymers [38]. An OH- radical, as shown in "Fig. 2" can also react readily with phenols. 
"Fig. 2" reactions enable further polymerization reactions, generating a 3-dimensional aromatic core net and constructing humic materials center in the soil. These cores can react further, including polysaccharide sugars, amino acids, peptides, and other compounds. In the case of the catechol and glycin reactions (Figure 3), [5] describes the incorporation of essential amino acids into or forming nitrogenous brown polymers/Humic substances.

Within polymerisation reaction products, the various mesomeric forms of Hydroquinone radicals enable the creation of distinct irregular kinds of -C-O-C- and -C-C- bonding. Hydroquinone reacts with an alkaline solution by forming aromatic and brown high molecular weight reaction products. The alkaline solution also produces catechol or o-dihydroxyphenol in such a way, which is brown or highly molecular, but resorcinol, or, in other words, $\mathrm{m}$ dihydroxyphenol, doesnot polymerize in an alkaline solution. [37] showed various mechanisms by which lignin degradation might lead to the polymerisation of phenylpropene units.

They showed that phenols do not polymerize into humic compounds when they are methylised within the phenol ring. In agreement with the concept of humic formation [38], [40] lignin reacted more or less by humic like pyrogallol polymer was chemical-integrated into the humic structure. [41]. It has also revealed that some fungal melanins, as assessed by pyrolysis mass spectrometry, are comparable to soil humic acids. The incorporation into humic polymers of nitrogen $(\mathrm{N})$ through the creation of -C-N-C- or C-=N-C bonds[38] is likely to result in an organic soil N-Fraction that is not hydrolysable and is defined as acid-insoluble $\mathrm{N}$ with hot $6 \mathrm{M} \mathrm{HCl} \mathrm{[5].} \mathrm{An} \mathrm{OH}$ radical, as shown in "Fig. 2" can also react readily with phenols.
"Fig. 2" processes enable further polymerization processes, generating a 3-dimensional aromatic nucleus net and constructing the center of humic materials in the soil. These cores can react additional, including polysaccharide sugars, amino acids, peptides and other compounds. In the case of the catechol and glycin reaction "Fig. 3" [5] describes the integration of essential amino acids into or forming nitrogenous brown polymers/Humic substances.

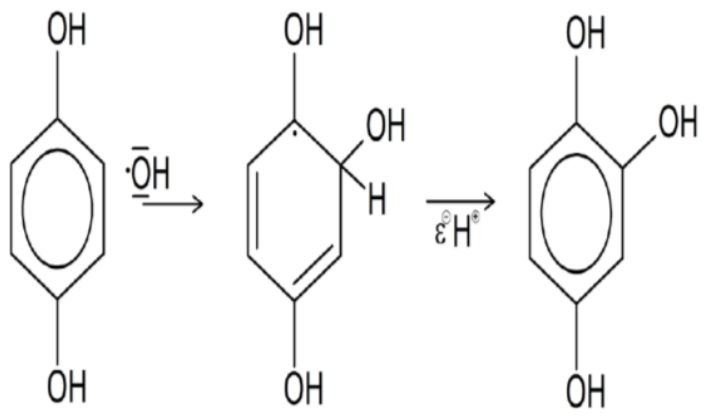

Figure 2. A third OH- group is to be introduced [38].

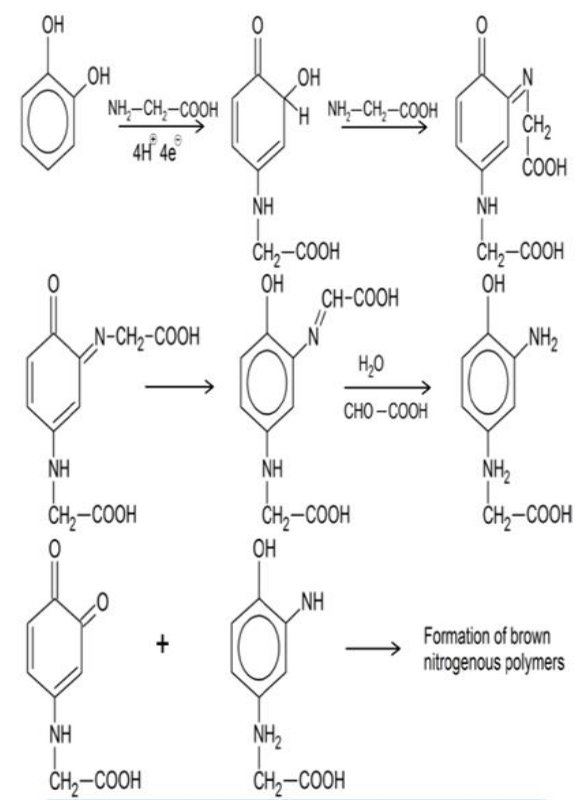

Figure 3. Catechol and glycine creation of humic substances [5].

Radical creation of phenols and their polymerisation are essential in the processes for the production of Humic compounds. Soil microbes may be capable of producing humic acid synthesis, such as polymers [39]. The 
constant supply of polyphenols is required for the development of humic materials due to the breakdown of lignin molecules and microbial production. Exoenzymes for example oxidoreductases or phenoloxidases may accelerate the production and polyfluorisation of radicals, as evidenced by the [42-44] transfer of the supramolecular structure of humic compounds into covalently-related polymers with peroxidase.

$\mathrm{Mn}$ and Fe on mineral surfaces, as proven by [45-47], are additional catalysts for the humic polymerization. Fe and $\mathrm{Mn}$ was responsible for this catalytic activity, also found on mineral surfaces [46], [48]. Silicon acid was found to act as a catalyst for development of hydroquinone humic polymers, but the question of whether it has an effect caused by the contamination of Fe or $\mathrm{Mn}$ remains unclear. Further soil humic reactions might potentially include polycondensation reactions and electrostatic interactions such as the reaction of basic amino acids with negative humic groupings or creation of bonds formed by hydrogen, charging complex transmission or hydrophobic contact between humic molecules.

In spite of the variations of the specifics of the concepts of polymerisation and soil formation across different study groups, four central, experimentally supported assumptions have so far agreed on the ideas reported:

1. In the soil, dead organic matter is partially degraded and broken down into small units, primarily by plants and soil microbes.

2. The other molecules, soil and oxidoreductases, as well as mineral surfaces, help to catalyze the reaction., react, polymerize and polycondensate to produce organic material with a medium to higher molecular weight, especially humic compounds. Super molecular bonds resulting in a humic network are formed by humic molecules with differing molecular weights.

3. Humic compounds have strong resistance and microbial degradation stability due to, among other things, the biochemical stability of microbial assault molecules [49],[50] and to the humic components in and after the production of the humic components. This results in the formation of complex clay-humic substances or in the form of complex humic substances, with di- or trivalent cations like $\mathrm{Cu}$ (II), $\mathrm{Ca}^{2+}, \mathrm{Al}$ (III) or Fe (III). The degradation rate of organic molecules in the soil was reduced, both through sorption on mineral surfaces and by cation complexation. [51], [52].

4. The chemical results allow structural components for humic materials to be created. [5] Provides an overview of several models of humic compounds. The majority of them are aromatic in nature, although the patterns are variable in aromaticity and intra-molecular weight [36], [53].

\subsection{The Humic Substances Benefits}

Although scientific experts were avoided by the whole composition of humic compounds, their effects have been widely investigated on .anything from apples to courgettes Humic substances are king for their ability:

- Improve soil nutrient absorption, particularly phosphorous, sulfur, and nitrogen.

- Improve soil nutrient absorption, particularly phosphorous, sulfur, and nitrogen.

- Reduce the need for nitrogen fertilizer. Toxins in the soil and animal products must be removed. 
- Stimulating bioactivity in the soil.

- Solubilizing minerals.

- Improving the soil structure.

- Acting as a storeroom for N, P, S, and $\mathrm{Zn}$ [54].

- Improving water retention capacities to increase dry resistance and water consumption reduction.[55],

The USDA-ARS soil laboratory in Minneapolis has conducted extensive research into the stimulating effects of humic chemicals [56], [57], [58] and globally.

The majority of Eastern European research on nitrogen utilization optimization has not been translated into English [56]. Nitrogen can be a structural component of humic substances as a persistent organic material and avoid leaking through the soil depending on the kind of fertilizer used. [60, 61] Humic compounds contain between $1 \%$ and $5 \%$ nitrogen in their natural condition. While all human compounds, irrespective of origin or molecule weight, are able-based, [62], [63], numerous humic substance sellers make claims regarding their products on the basis of the arbitrary classifications of "humic acid" and "fulvic acid" content. [25]

\subsection{Humic Impact on Soil Characteristics}

The humic compounds adding to the soil can have major physical, chemical and biological effects on the soil. Increased water retention, infiltration rates, soil aggregation, and water holding capacity [31] are supplemented with organic matter such as humic compounds.

"It has been discovered that adding humic aggregations to soils with a variety of texture grades and mineral suites improves [35] "The aggregation impact seems to differ depending on the source of the humic compounds. As sandy and clay soils were treated with a tube extracted humic material $(<1000 \mathrm{~mm})$, the amount of fine aggregates $(<1000 \mathrm{~mm})$ was increased [35].When sandy and clay soils were treated with a manure-extracted humic material, the amount of large aggregates (1,5002,500mm) increased [35].Aggregation supports high rates of infiltration, reducing runoff and erosion [64]. The application of humic compounds also affects the cation exchange capacity of the ground. "Humus accounts for between 50 and 90 percent of the mineral surface of the soil's cation-absorbing energy. The humus colloids, like clays, are quickly replaced with nutritional cations (potassium, calcium, magnesium, and so on) that are not rapidly removed from the profile by percolating water [31].

How comparable are the substances applied to the humic compounds in the native soil that are affected by the origin of the material and the treatment methods? [65] is the effectiveness of humic substances. 'The larger and more compositional, structural and functional characteristics of humic substances such as fractions resembling those of the native soil [hume] contribute to the fundamental functions of global soil fertility and soil health, the more agriculturalally efficient, safe and cost-effective is the organic modification.'[65] Transformed humic compounds typically have higher concentrations of hydrogen, carbon, sulfur, and nitrogen in the COM.

Relative to natural soil humic substances [65]. When humic composted items, like sewage sludge, animal waste and food waste, are applied to a wide range, the molecular characteristics of the humic substances in native soils tend to over time match their molecular properties [65]. When they are used to treat various types of soil, the influence of humic compounds also varies according to the source, plant species and way of application of the 
humic compound [66]. Several rates of humic acid were administered to plots in a randomized full block in an experiment done in Idaho Saylor Creek. At 3, 7, 15, 30 and 60 L/humic acid/acre rates, a $6 \%$ humic acid solution was used [66]. Three separate farmers' fields are situated on the plots. Calcareous soils $(\mathrm{pH} 8$ 8.2) were present in the fields with an organic matter concentration of around $1 \%$. In plots of potatoes, humic acid has been planted and administered on each side of the lines by side dressings [66]. stand and vigor has increased compared to control plots in plots treated with humic acid [66]. The rate of application of humic acid rose to $30 \mathrm{~L} /$ humic acid/acre, but lowered by $60 \mathrm{~L} /$ humic acid/acre the maximum treatment [66]. The impact of humic acid on the reactions of organic-clay complexes might have a negative influence on output [66].

While Seyedbagheri administered granular and liquid humic acidification into plots of calcareous silt clay Loam, there's no substantial difference in outputs between treatments for humic acid and control [66]. Granular humates were dressed at $16 \mathrm{~kg} / \mathrm{acre}$ and fluid humate was put to a side dish at 0,18 and 37 1/humic acid/acre [66].

\section{Nitrogen Management}

Other effects of humic substances include increased cation-exchange capacity, soil structure stabilization [67] and nitrogen fertilizer reduction. [26], [69]. There is good evidence of the importance of humic materials to soil fertility as well as nitrogen stabilization [61], [69], [70]. A study by a science team from the A\&M University of West Texas and the USDA-ARS [71] showed the potential of humic substances to decrease the emissions of ammonia from feed lots. If enough humical substances are present, at the end of the first season it can be kept in organic forms up to $35 \%$ of the soluble nitrogen applied to soils as fertilizer [72], thus converting $\mathrm{N}$ into a stable, but still bioavailable form. In the public sector and the federal government, the ecological impact of the nitrogen used for turf grass is increasingly being studied. Due to this pressure, the most widely used organic materials have become humic substances in the management of golf field turf [73]. C.-Edward Clapp of the USDA-ARS, Minneapp, Soil, Water \& Climate Department, recommends the use of humic substances for nitrogen leaching on golf courses after 45 years of research [56]. A thorough review of the scientific literature has not shown much about the use of humic substances in agriculture in practical terms. In Russia there are numerous references to a broad spectrum of research not translated into English. In a recent reference [74], the majority of the information is entered into the university as internal reports.

\section{Criticism of the Concept of Humic Substances}

Several papers have criticized or rejected the hereby mentioned concept [75-79] propose a 'traditional view' on soil organic matter a new and emerging perspective (Humic Substances Concept). The following mention is some of the misunderstandings. The central reaction of soil humic substances, as demonstrated previously, the chemical or biochemical polymerisation of phenol units through soil oxidation reducastics, soil mineral surfaces and microorganisms, such as soil fungi and human aggregations. Lehmann [80], The humic polymerization theory did not collect the arguments; they did not even indication it. Rather, they suggest the method of "progressive degradation" and "selective preservation". Main components such as lignin, cellulose and protein, as they stand for organic soils, are degraded by micro-organisms with a medium residence duration.Any grounds for the failure to polymerize or react further, e.g, with 
amino sugars or amino acid phenol units or phenols derived from lignin decomposition are not indicated or indicated [80]. They mainly based their paper on opposing the "traditional view" and "emergent view" of humic substances.

[80] Has shown that their knowledge of human substances is limited, however, by at least two points. They criticize the alkaline extraction of humic substances 0.1 or $0.5 \mathrm{M} \mathrm{NaOH}$ which can generate artifacts, in particular during mining in an $\mathrm{O}_{2}$ atmosphere with some justification. But the use of mild extraction solutions (such as $\mathrm{pH}$ 7.0 or $\mathrm{pH} \quad 8.5$ dimethylformamide or dimethylsulfoxide) [5],[38],[81], is ignored. The detailed discussion of soil organic matter extraction by [81] in particular is overlooked by [81]. By applying humic substances to the soil solution for further examination, the problem of objects forming during extraction can be minimized. Most seriously, "harsh treatments with $\mathrm{pH} 13$ ionized compounds are advocated, in which a $\mathrm{pH} \mathrm{pH}(\mathrm{pH} 3.5-8.5)$ would never be distinguished within the larger soil $\mathrm{pH}$ range" [80]. Otherwise, as [80]'It is remarkable for materials extracted at $\mathrm{pH} 13$ to be considered as the result of a chemical fractionation process that ionizes all the carboxyl groups (compared with the decomposite state of the functional group at $\mathrm{pH} 13$. This is perhaps why in the operationally defined has (humic acids), there are more carboxylic groups than in most natural compounds." The authors postulate that the acidity of carboxylic groups at $\mathrm{pH} 13$ are determined by "ignorant" humic chemists. The author also states [79], [80]. The $\mathrm{COOH}$-acidity of humic substances is, however, based on a wide-range $\mathrm{pH}$ titration method [36] or a Caacetate procedure [82]. The reason why $\mathrm{COOH}-$ groups are often relatively high is not the presumed $\mathrm{pH}-13$. Clearly, we have no idea that the $\mathrm{pH}$ of the extracting solution is not the same as the $\mathrm{pH}$ of the extracting solution. of the $\mathrm{COOH}$ and $\mathrm{OH}$-acidity determinations. In addition, $\mathrm{COOH}$ groups' operational definition derives from the techniques employed is known to be soil chemical humic substances. The ignorance of humic substances in the paper [80], as well as the lack of structure in the review of [79], This leads to a lack of a realistic idea of converting organic soil material. The repercussions of neglecting the functioning of humic substances in the soil, from phenolic units' polymerisation to humic soil formation, may be deficient in considering the basic ground/plant system processes. Another criticism of the concept of humic substances can be found in, for example, [75], [76]. The two research groups mainly attributed aromatic carbon to fired organic carbon or black carbon within the soil organic matter. They were dispensed from research on humic substances in soil by this interpretation. This view may imply, as suggested by [80], that pathogens simply exist in the soil. If so, what is the BC framework that has been emphasized for more than two decades in soil organic matter research?

\section{Black Carbon in Soil}

Since the basic publication of [83], black carbon (BC) from organic material, in soil organic matter studies, fire-affected soil has gotten a lot of interest. The key question, however, is how much BC exists in the soil? [84] BC was studied as a biomass by-product with characteristics ranging from mildly burned biomass through charcoal, coal, and finally soot, described as a combustion continuum. The high carbon content, heterogic and aromatic structures, from oxygenation-driven aromatic ring structure to polycyclic aromatic hydrocarbons, are dominant in all these fire-affected components [85]. BC's determination has been a matter of debate for many years. All the important methods for determining $\mathrm{BC}$ [86], [87] are thermal 
oxidation, pre-extraction and thermal oximation combinations, oxidation, subsequent application of Benzepolycarboxylic acids (BPCAS), and UV-irradiation oxidation. However, assessment of the methods by different scientific groups for soil $\mathrm{BC}$ determination reveals that there is still no strong experimental basis for determining BC. Comparative results were reported on the BC content of eight soils in Australia based on different methods [86]. Four out of six methods for the detection, without or with pre-extraction, of the BC thermal oxidation used at 340 or 370 _C, with $\mathrm{Bc}$ attributing loss after heating. The fifth process used the oxidation of benzene polycarboxylic acids (BPCA) and the subsequent determination as $\mathrm{BC}$ markers [88]. Finally, in CP MAS13C NMR spectroscopy, the sixth approach has been the UV Oxidation of soil organism with organic residue as BC [89],[90]. There are remarkable comparative results [86]. $\mathrm{BC}$ rates were 4 to 6 percent (BC/ total organic soil). Pre-extraction with strong acids or in combination with $\mathrm{NaOH}$ reduced the measured $\mathrm{BC}$ values on the same soils to values of 0.05-3.95 percent $\mathrm{BC}$ in the 8 soils investigated, whereas pre-extraction with strong acids or in combination with $\mathrm{NaOH}$ reduced the measured $\mathrm{BC}$ values on the same soils to values of 0.05-3.95 percent BC [86]. Thermal oxidation without pre-extraction was achieved in the same soils. This reduction may be explained by the fact that soil organic matter and in particular humic material pre-extraction will reduce artifacts during the heating process during the $\mathrm{BC}$ determination. Thus, the accuracy of the $\mathrm{BC}$ determination through thermally oxidating methods requires a suitable preextraction step [91]. Due to BC formation during thermal oxidative treatment, thermal oxidative methods were shown to be able to overestimate the $\mathrm{BC}$ content. $\mathrm{BC}$ values around 3.7 and 13.1 percent $\mathrm{BC}$ were found in eight soles using the BPCA marker method [75].
These values are 2-10 higher than those obtained through thermal oxidation methods and the content of the soil BC itself is overestimated. During the analytical procedure, the possibility of oxidation of humic substances into BPCAs during the BC-overestimation was unchecked [75]. This is not possible. The BC surplus with the BPCA marker method has been demonstrated [92]. The $\mathrm{HCl}$ pretreatment was found to create more BPCAs, which resulted in a strong $\mathrm{BC}$ overestimation. The pretreatment of $\mathrm{HCl}$ was performed by [86], [88]. The UV method was the sixth method used by [86]. This approach is followed by the destruction of soil organic matter by high-intensity UV radiation and NMR Spectroscopy of the remaining organic $\mathrm{C}$ as $\mathrm{BC}$. The UV method gave concentrations of $\mathrm{BC}$ in the same eight soils of between 1.14 and $32.5 \%$. The UV-determined $\mathrm{BC}$ values were exceeded by thermal oxidation factors of up to 500 [86] in six of the eight soles, with the highest values being by far the highest. The pretreatment with UV obviously didnot destroy all the organic soil which was not the case in BC UV irradiation resistance is moderate are humic substances [93][94]. Part of the humic substances therefore survive the irradiation and are determined to be BC. In summary, the BPCA marker and UV irradiation method have demonstrated high $\mathrm{BC}$ values, which outperform pre-extraction by factors ranging from 10 to 100 the more reliable thermal oxidation method. These discrepancies were not discussed in the authors' papers, however. a number of $\mathrm{BC}$ methods also were examined, and both "potential interfering materials" were evaluated [87]. Among other materials they used $\mathrm{BC}$-free lignite coal and BC-free bituminous coal of up to 10 percent. The method of the BPCA markers yielded a BCfree coal yield of 23.4 percent $\mathrm{BC}$ and the UV method yielded $26.9 \%$ BC. For bituminous coal, the UV method has yielded BC by up toward 
90\% [87] despite the true $\mathrm{BC}$ contents of 0 to $10 \%$ [95] Recently, as determined by the BPCA marker method, BC-free plant materials have yielded to some extent BC. Probably a strong overestimation of the $\mathrm{BC}$ by the BPCA marker method to determine BC in soil [88] [96]. Conclusions regarding Terra fertility are drawings of wet tropical soils [76]. After publishing a method-comparing study by [86], [92] the authors should have been critically evaluated. The obvious lack of UV methods in soil to determine accurate $\mathrm{BC}$ values [86] has not prevented [96] publication of $\mathrm{BC}$ content results from Chernozems in Europe, with extremely high $\mathrm{BC}$ values in soil-organic matter were measured between $15 \%$ and $35 \%$. Moreover, [97] hasn't stopped publishing BC data for US soils of 10 to 35 per cent. The selected method was the UV method in both cases [87] the purpose of checking BC methods in soils. They were using melanoidine, which according to a single reference was stated to have "like chemistry as natural organic matter." Obviously, humic substances were avoided as reference material. Recall that fuse aromatic rings are also contained in humic substances [36], [53], [98], which can be measured as BC, e.g., through the BPCA method marker. No assessment was made of the potential interference of soil humic substances in determining BC [87]. The effect of humic substances on the determination of BC would have been evident without the use of "natural" humic substances as reference material using models polymers such as hydroquinone, catechol or pyrogallol. The high $\mathrm{BC}$ values found in [75], [96], [97], [99], and the BPCA marker method, are currently not reliable. Glaser [99] Rather, they likely constitute a strong BC overestimate and the findings of these values should be reassessed as a matter of urgency. The picture is more difficult, however. Multiple mechanisms may be used to interact in soil, as shown in "Fig.4".

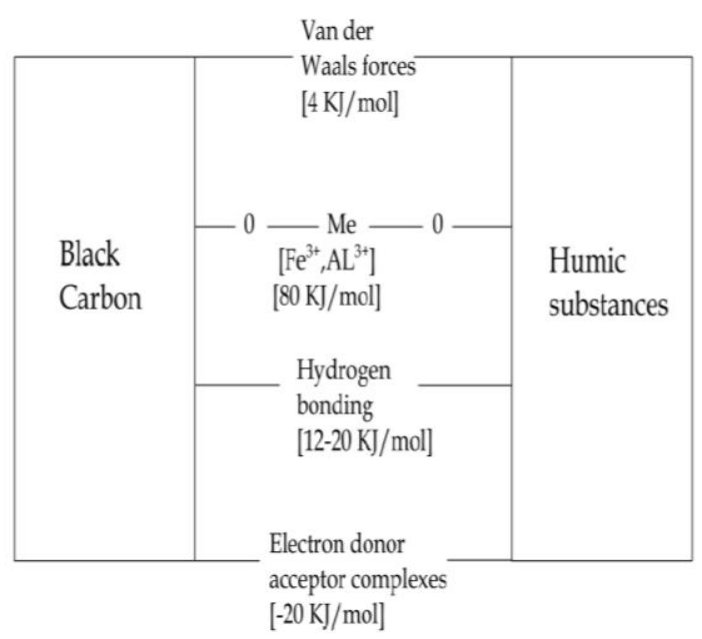

Figure 4. Main chemical interactions with humic substances between black carbon molecules. Approximate binding energies are in square brackets.

\section{7- Organic Xenobiotic Reactions of Humic Materials}

\subsection{Triazines Reaction:}

Senesi and Wegener [100]-102] examined in detail how the ion-yon interactions and the electron donor-acceptor complexes interacted with triazines and humic substances as the principal link mechanisms leading to an important integration of triazine molecules into the humic framework. For the strong binding of atrazine molecules, the content of phenolic $\mathrm{OH}$ groups is highly relevant [102].

\subsection{Humic Substances and Surfactants Interaction}

As organic pollutants, surfactants play an significant role. The reaction between the cationic surfactant and the anione, dodecylpyridine chlore (DPC), respectively, a linear $\mathrm{Na}$ dodecyl brain sulfone (LAS), and the weak hydrophobial interaction between humic and anionic surfactants, has been examined [103]. In the presence of humic substances, the photodegradation of the cationic surfactant was greatly increased, whereas the photo- 
degradation of the anionic LAS has been reduced in the presence of humic substances [104], [105]. A series of radials OH-, R-COO and $\mathrm{O}_{2}$ [104], [106], was photo-oxidized by humic substances which induced a greater photo-degradation of bonding DPC molecules than a photo-oxidation system. Therefore, photodegradation of soil surfactants can not be described without an understanding of the physicochemical characteristics of soil humic compounds

\section{Soil Reactions of Humic Substances with Inorganic Ions}

\subsection{Micronutrient Metal Reactions}

Without considering the interface between metals and soil humic substances, the obtainability of micronutrients in the soil, in particular $\mathrm{Cu}$ and $\mathrm{Fe}$, cannot be clarified. $\mathrm{Fe}^{3+}$ and its monomeric hydroxy species are soluble and strongly dependent on their associated organic soil, humic, compounds. In the soil, Fe is transported to the root zone depends strongly on the soil solution concentration. That is frequently regulated by organic $\mathrm{Fe}$ (III) complexes with low concentrations. The Strategy I strategy for acquiring Fe from soil was described by molecular weight organic or dissolved humic anions [107-109].This strategy involves transportation of $\mathrm{Fe}$ (III) organic compound with low molecular weight or humicFe (III) complex to the plant root in the soil solution; the reducing of Fe (III) to the root of the plasma membrane-bound oxidoreductase (PB); the release of $\mathrm{Fe}$ (II) from organic complexes due to the much lower core composition; The reduction of Fe (II) [110]. Has been shown to make great use of fe in Fehumate complexes as a strategy of planting species I [111]. Has examined the potential to improve feeding for higher $\mathrm{pH}$ plants, with high Fe solubility frequently low in humic substances
[111]. The availability of $\mathrm{Cu}$ in the soil is heavily affected by humic substances. Most $\mathrm{Cu}$ is organically bound in the soil solution [107]. That is, most of the $\mathrm{Cu}$ carried to the root in the soil is organically complicated. However, $\mathrm{Cu}$ is often firmly bound to the unresolved organic matter in soils high in humified organic matter, such as peaty soils, and it can induce a Deficiency of copper $(\mathrm{Cu})$ in higher plants, which highlights the relevance of humic compounds in the availability of $\mathrm{Cu}$ [112] for the interactions between metals and humic materials.

\subsection{Al (Fe) Humic Soil Phosphate Complexes}

Humic substances form orthophosphate (P) complexes that are of great importance in the different soils through the bridges of Fe (III) or Al(III)[113],[114]. The soil availability of soil humic substances is often assumed as a result of competitive adsorption binding on the same soil sites for adsorption [115], [116]. However, Gerke [52] demonstrated that $\mathrm{P}$ can be mobilized easily by organic acid anions in humic $\mathrm{Fe}$ (Al)-P complexes or after acidification,that could be evidence for comparatively high obtainability of humicrelated P in soil. Some Spanish scientists on the soil, plant nutrition and supervisors of production are employed on the using humic substances for fertilizer production [98], [117] stressing the impact of humic substances on the availability of $\mathrm{P}$ and micronutrients. Speciation of p-solution and algae availability $\mathrm{P}$ can also be controlled in lakes by humic-associated phosphate [118], [119].

\section{Conclusions}

Organic macromolecules are humic substances with various characteristics and structural high complexity. They are abundant in soil, natural water, and a variety of other terrestrial and 
aquatic environments. The group of humic substances can be divided into 3 components, based on their solubility: fulvic acids, humic acids and humin. Fulvic acids and humic acids form alkaline-soluble humus fragments of which the insoluble residue is moist. As regards the structure, Havel Sanskrit has not yet made a breakthrough with CE and MALDI-TOF MS, indicating that HAs are not highly molecular compounds. Regardless of the unknown fabric and the effort to electrolucize the humic substances, carboxylic, phenolic, carbonyl, hydroxyl, amine, amide, aliphatic, and other moieties are the main functional groups. Due to this polyfunction, humic materials are the strongest chelating agents among natural organic substances. Anions interact with positive humic and cational groups of these substances with negative charging groups due to their twitterionic nature. A large variety of organic modules, including sugars, amino acids, lignin fragments peptides, and xenobicides, like pesticides and surfactants, are available. You have a one-of-a-kind skill. Due to this synthesized path, the aromatic core of humic soils is usually between $30 \%$ and $60 \%$. Humic substances have high water holding capacity, high water exchange capabilities and adsorption capacities of complicated cationic nutrients, as well as the ability to provide significant $\mathrm{P}$ for the soil. Humic substances include high chemical and physical purposes in the soil, including high water-supporting capabilities and heavy metals, such as $\mathrm{Pb}$ or $\mathrm{Cd}$. Humic substances also contain and strengthen xenobiotics such as pesticides, PAHs or soilcausing surfactants. The soil of higher plants can be improved by humic substances or some of their fractions, probably by various mechanisms.

\section{Conflict of Interest}

The authors declare that there is no conflict of interest regarding publication of this manuscript.

\section{References}

1. Baldock, J. A. and Smernik, R. J. (2002). "Chemical composition and bioavailability of thermally altered Pinus resinosa (Red pine) wood", Organic Geochemistry. Elsevier, 33(9), pp. 1093-1109.

2. Belnap, J., Weber, B. and Büdel, B. (2016). "Biological soil crusts as an organizing principle in drylands", in Biological soil crusts: an organizing principle in drylands. Springer, pp. 3-13.

3. Benites, V. de M. et al. (2010). "Análise discriminante de solos sob diferentes usos em área de Mata Atlântica a partir de atributos da matéria orgânica", Revista Árvore. SciELO Brasil, 34(4), pp. 685690.

4. Borggaard, O. K. et al. (2005), "Influence of humic substances on phosphate adsorption by aluminium and iron oxides", Geoderma. Elsevier, 127(3-4), pp. 270279.

5. Boudot, J.-P. (1992). "Relative efficiency of complexed aluminum noncrystalline Al hydroxide, allophane and imogolite in retarding the biodegradation of citric acid", Geoderma. Elsevier, 52(1-2), pp. 29-39.

6. Brady, N. C., Weil, R. R. and Weil, R. R. (2008). "The nature and properties of soils", Prentice Hall Upper Saddle River, NJ.

7. Brodowski, S. et al. (2005). "Revised black carbon assessment using benzene polycarboxylic acids", Organic Geochemistry. Elsevier, 36(9), pp. 12991310.

8. Calvo, P., Nelson, L. and Kloepper, J. W. (2014). "Agricultural uses of plant 
biostimulants", Plant and soil. Springer, 383(1), pp. 3-41.

9. Canellas, L. P. et al. (2004). "Organic matter quality in a soil cultivated with perennial herbaceous legumes", Scientia Agricola. SciELO Brasil, 61(1), pp. 5361.

10. Canellas, L. P. et al. (2007). "Estoque e qualidade da matéria orgânica de um solo cultivado com cana-de-açúcar por longo tempo", Revista Brasileira de Ciência do Solo. SciELO Brasil, 31(2), pp. 331-340.

11. Cesco, S. et al. (2002). "Uptake of $59 \mathrm{Fe}$ from soluble $59 \mathrm{Fe}$-humate complexes by cucumber and barley plants", Plant and Soil. Springer, 241(1), pp. 121-128.

12. Chen, J. et al. (2002). "Spectroscopic characterization of the structural and functional properties of natural organic matter fractions", Chemosphere. Elsevier, 48(1), pp. 59-68.

13. Chen, Y. et al. (1999). "Stimulation of plant growth by humic substances: effects on iron availability., Understanding humic substances. Advanced methods, properties and applications", Royal Society of Chemistry, pp. 255-263.

14. Chen, Y., Magen, H. and Clapp, C. E. (2001). "Plant growth stimulation by humic substances and their complexes with iron", in. International Fertiliser Society.

15. Clapp, C. E. et al. (1998). "Humic substances for enhancing turfgrass growth", GB Davies and EA Ghabbour (ed.).

16. Clapp, C. E. et al. (2001). "Plant growth promoting activity of humic substances", Understanding and managing organic matter in soils, sediments, and waters. International Humic Substances Society: St. Paul, MN, pp. 243-255.
17. Clemente, J. S. et al. (2013). "Comparison of soil organic matter composition after incubation with maize leaves, roots, and stems", Geoderma. Elsevier, 192, pp. 8696.

18. Cooper, W. J. and Zika, R. G. (1987). "Photochemistry of environmental aquatic systems, Amer Chemical Society.

19. Cozzolino, A. and Piccolo, A. (2002). "Polymerization of dissolved humic substances catalyzed by peroxidase. Effects of $p H$ and humic composition", Organic Geochemistry. Elsevier, 33(3), pp. 281-294.

20. Cucunubá-Melo, J. L., Álvarez-Herrera, J. G. and Camacho-Tamayo, J. H. (2011). "Identification of agronomic management units based on physical attributes of soil", Journal of soil science and plant nutrition. Chilean Society of Soil Science, 11(1), pp. 87-99.

21. Erro, J. et al. (2016). "Incorporation of humic-derived active molecules into compound NPK granulated fertilizers: main technical difficulties and potential solutions", Chemical and Biological Technologies in Agriculture. SpringerOpen, 3(1), pp. 1-15.

22. Fataftah, A. K. et al. (2001). "A comparative evaluation of known liquid humic acid analysis methods", SPECIAL PUBLICATION-ROYAL SOCIETY OF CHEMISTRY. Royal Society of Chemistry; 1994, 273, pp. 337-344.

23. Flaig, W., Beutelspacher, H. and Rietz, E. (1975). "Chemical composition and physical properties of humic substances", in Soil components. Springer, pp. 1-211.

24. Francko, D. A. and Heath, R. T. (1979). "Functionally distinct classes of complex phosphorus compounds in lake water 1", Limnology and Oceanography. Wiley Online Library, 24(3), pp. 463-473. 
25. Frank, K. D. and Roeth, F. W. (1996). "Using soil organic matter to help make fertilizer and pesticide recommendations", Soil organic matter: Analysis and interpretation. Wiley Online Library, 46, pp. 33-40.

26. Fu, Z. et al. (2013). "Competitive interaction between soil-derived humic acid and phosphate on goethite", Applied Geochemistry. Elsevier, 36, pp. 125-131.

27. Gerke, J. (1995). "Chemische Prozesse der Nährstoffmobilisierung in der Rhizosphäre und ihre Bedeutung für den Übergang vom Boden in die Pflanze", Cuvillier.

28. Gerke, J. (1997). "Aluminum and iron (III) species in the soil solution including organic complexes with citrate and humic substances", Zeitschrift für Pflanzenernährung und Bodenkunde. Wiley Online Library, 160(3), pp. 427432.

29. Gerke, J. (2010). "Humic (organic matter)-Al (Fe)-phosphate complexes: an underestimated phosphate form in soils and source of plant-available phosphate", Soil Science. LWW, 175(9), pp. 417-425.

30. Gerke, J. (2015). "The acquisition of phosphate by higher plants: effect of carboxylate release by the roots. A critical review.", Journal of Plant Nutrition and Soil Science. Wiley Online Library, 178(3), pp. 351-364.

31. Gerke, J. (2018). "Concepts and misconceptions of humic substances as the stable part of soil organic matter: A review", Agronomy. Multidisciplinary Digital Publishing Institute, 8(5), p. 76.

32. GERKE, J. and ZIECHMANN, W. (1990). "Adsorption des kationischen Tensids Laurylpyridiniumchlorid an Huminstoffe, Böden und Komposte", Chemie der Erde, 50(4), pp. 247-253.
33. Ghabbour, E. A. and Davies, G. (2000). "Humic substances: versatile components of plants, soil and water", Proceedings of the Fourth Humic Substances Seminar held at Northeastern University, Boston, Massachusetts, USA, on 22-24 March ', Royal Society of Chemistry.

34. Glaser, B.; Haumeier, L.; Guggenberger, G.; Zech, W. T. T. (2001). "The'Terra Preta'phenomenon: a model for sustainable agriculture in the humid tropics", Naturwissenschaften. Springer, 88(1), pp. 37-41.

35. Glaser, B. et al. (1998). "Black carbon in soils: the use of benzenecarboxylic acids as specific markers", Organic geochemistry. Elsevier, 29(4), pp. 811819.

36. Glaser, B. et al. (2000). "Black carbon in density fractions of anthropogenic soils of the Brazilian Amazon region", Organic Geochemistry. Elsevier, 31(7-8), pp. 669678.

37. Goldberg, E. D. (1985). "Black carbon in the environment: properties and distribution", John Wiley and Sons, New York, NY.

38. Gude, A., Kandeler, E. and Gleixner, G. (2012). "Input related microbial carbon dynamic of soil organic matter in particle size fractions", Soil Biology and Biochemistry. Elsevier, 47, pp. 209-219.

39. de Haan, H., Jones, R. I. and Salonen, K. (1990). "Abiotic transformations of iron and phosphate in humic lake water revealed by double-isotope labeling and gel filtration", Limnology and oceanography. Wiley Online Library, 35(2), pp. 491-497.

40. HAIDER, K. (1991). "in Soils of Temperate Climates", Soil biochemistry. CRC Press, 7, p. 55. 
41. Haider, K. M. et al. (1977). "Studies on soil humic compounds, fungal melanins and model polymers by pyrolisis massspectrometry", International Atomic Energy Agency.

42. Haider, K. and Martin, J. P. (1967). "Synthesis and transformation of phenolic compounds by Epicoccum nigrum in relation to humic acid formation", Soil Science Society of America Journal. Wiley Online Library, 31(6), pp. 766-772.

43. Hammes, K. et al. (2007). "Comparison of quantification methods to measure firederived (black/elemental) carbon in soils and sediments using reference materials from soil, water, sediment and the atmosphere", Global Biogeochemical Cycles. Wiley Online Library, 21(3).

44. Hayes, M. H. B. (2006). "Solvent systems for the isolation of organic components from soils", Soil Science Society of America Journal. Wiley Online Library, 70(3), pp. 986-994.

45. Hens, . (1999). "Aqueous Phase Specification of Phosphorus in Sandy Soils", Katholieke Universiteit Leuven.

46. Hermann, R. (1993). "Modifiziertes Reaktionsverhalten von Huminstoffen infolge photochemisch induzierter Prozesse gegenüber ausgewählten organischen Substanzen und anorganischen Ionen", Cuvillier.

47. Hermann, R., Gerke, J. and Ziechmann, W. (1997). "Photodegradation of the surfactants Na-dodecylbenzenesulfonate and dodecylpyridinium-chloride as affected by humic substances", Water, Air, and Soil Pollution. Springer, 98(1), pp. 43-55.

48. Huang, S. et al. (2010). "Soil aggregation and organic carbon fractions affected by long-term fertilization in a red soil of subtropical China", Geoderma. Elsevier, 154(3-4), pp. 364-369.

49. Janoš, P. (2003). "Separation methods in the chemistry of humic substances", Journal of Chromatography A. Elsevier, 983(1-2), pp. 1-18.

50. Jones, R. I. (1998). "Phytoplankton, primary production and nutrient cycling", in Aquatic humic substances. Springer, pp. 145-175.

51. Jones, R. I., Shaw, P. J. and De Haan, H. (1993). "Effects of dissolved humic substances on the speciation of iron and phosphate at different $\mathrm{pH}$ and ionic strength", Environmental science \& technology. ACS Publications, 27(6), pp. 1052-1059.

52. Kalantari, B. and Huat, B. B. K. (2008). "Peat soil stabilization, using ordinary portland cement, polypropylene fibers, and air curing technique", Electron. J. Geotech. Eng, 13, pp. 1-13.

53. Kappenberg, A. et al. (2016). "Black carbon assessment using benzene polycarboxylic acids: Limitations for organic-rich matrices", Organic Geochemistry. Elsevier, 94, pp. 47-51.

54. Karr, M. (2001). "Oxidized lignites and extracts from oxidized lignites in agriculture", Soil Science, pp. 1-23.

55. Kelley, K. R. and Stevenson, F. J. (1996). "Organic forms of $N$ in soil", in Humic substances in terrestrial ecosystems. Elsevier, pp. 407-427.

56. Kleber, M. et al. (2015). "Mineral-organic associations: formation, properties, and relevance in soil environments", Advances in agronomy. Elsevier, 130, pp. 1-140.

57. Kögel-Knabner, I. et al. (2008). "Organomineral associations in temperate soils: Integrating biology, mineralogy, and organic matter chemistry", Journal of 
Plant Nutrition and Soil Science. Wiley Online Library, 171(1), pp. 61-82.

58. Kononova, M. M. (1966). "Soil organic matter", 2nd English edition". Pergamon Press, Oxford.

59. Lehmann, J. and Kleber, M. (2015). "The contentious nature of soil organic matter", Nature. Nature Publishing Group, 528(7580), pp. 60-68.

60. Li, X.-G. et al. (2007). "Soil physical properties and their relations to organic carbon pools as affected by land use in an alpine pastureland", Geoderma. Elsevier, 139(1-2), pp. 98-105.

61. Loss, A. et al. (2016). "Fertilidad del suelo, fracciones húmicas y abundancia natural de $13 \mathrm{C}$ y $15 \mathrm{~N}$ en el suelo bajo diferentes usos del suelo en el estado de Paraná, Sur de Brasil", Idesia (Arica). Universidad de Tarapacá. Facultad de Ciencias Agronómicas, 34(1), pp. 27-38.

62. Lützow, M. v et al. (2006). "Stabilization of organic matter in temperate soils: mechanisms and their relevance under different soil conditions-a review", European journal of soil science. Wiley Online Library, 57(4), pp. 426-445.

63. MacCarthy, P. (2001). "The principles of humic substances: An introduction to the first principle", Special Publication-Royal Society of Chemistry. Royal Society of Chemistry; 1994, 273, pp. 19-30.

64. Marschner, H. and Römheld, V. (1994). "Strategies of plants for acquisition of iron", Plant and soil. Springer, 165(2), pp. 261-274.

65. Martin, J. P., Haider, K. and Bondietti, E. (1975). "Properties of model humic acids synthesized by phenoloxidase and autoxidation of phenols and other compounds formed by soil fungi", in Humic Substances: their Structure and
Function in the Biosphere Proceedings of an International Meeting.

66. Masiello, C. A. (2004). "New directions in black carbon organic geochemistry", Marine Chemistry. Elsevier, 92(1-4), pp. 201-213.

67. Moraes, G. M. de et al. (2011). "Chemical and structural characterization of soil humic substances under agroforestry and conventional systems", Revista Brasileira de Ciência do Solo. SciELO Brasil, 35(5), pp. 1597-1608.

68. Müller-Wegener, U. (1987). "Electron donor acceptor complexes between organic nitrogen heterocycles and humic acid", Science of the Total Environment. Elsevier, 62, pp. 297-304.

69. Müller-Wegener, U. (1993). "Einfluss von huminstoffen auf den eintrag von pflanzenschutzmitteln in das grundwasser", Refraktäre Organische Säuren in Gewässern; Frimmel, FH, AbbtBraun, G., Eds, pp. 79-87.

70. Nardi, S., Concheri, G. and Dell'Agnola, G. (1996). "Biological activity of humus", in Humic substances in terrestrial ecosystems. Elsevier, pp. 361-406.

71. Norambuena, M. et al. (2014). "Effect of liquid humus and calcium sulphate on soil aggregation", Journal of soil science and plant nutrition. Chilean Society of Soil Science, 14(3), pp. 701-709.

72. Oades, J. M. et al. (1987). "Characterization of organic matter in particle size and density fractions from a red-brown earth by solid state 13C NMR", Soil Research. CSIRO, 25(1), pp. 71-82.

73. Pagliai, M., Vignozzi, N. and Pellegrini, S. (2004). "Soil structure and the effect of management practices", Soil and Tillage Research. Elsevier, 79(2), pp. 131-143.

74. Perdue, E. M. (1985). "Acidic functional groups of humic substances". Wiley. 
75. Pettit, R. E. (2004). "Organic matter, humus, humate, humic acid, fulvic acid and humin: their importance in soil fertility and plant health", CTI Research, 10, pp. 1-7.

76. Piccolo, A. et al. (2000). "Polymerization of humic substances by an enzymecatalyzed oxidative coupling", Naturwissenschaften. Springer, 87(9), pp. 391-394.

77. Piccolo, A. and Mbagwu, J. S. C. (1999). "Role of hydrophobic components of soil organic matter in soil aggregate stability", Soil Science Society of America Journal. Wiley Online Library, 63(6), pp. 18011810.

78. Porta, J., Reguerín, M. and Roquero, C. (2003). "EDAFOLOGÍA Para la agricultura y el medio ambiente. tercera", Barcelona. España.

79. Quilty, J. R. and Cattle, S. R. (2011). "Use and understanding of organic amendments in Australian agriculture: a review", Soil Research. CSIRO, 49(1), pp. 1-26.

80. Rigobello, E. S. et al. (2017). "Comparative characterization of humic substances extracted from freshwater and peat of different apparent molecular sizes", Revista Ambiente \& Água. SciELO Brasil, 12(5), pp. 774-785.

81. Rosa, A. H. et al. (2005). "Multimethod study of the degree of humification of humic substances extracted from different tropical soil profiles in Brazil's Amazonian region", Geoderma. Elsevier, 127(1-2), pp. 1-10.

82. Russo, R. O. and Berlyn, G. P. (1991). "The use of organic biostimulants to help low input sustainable agriculture", Journal of Sustainable Agriculture. Taylor \& Francis, 1(2), pp. 19-42.
83. Santos, G. de A. (1999). "Fundamentos da matéria orgânica do solo", ecossistemas tropicais \& subtropicais. Gênesis.

84. Sarkhot, D. V et al. (2007). "Effects of forest management intensity on carbon and nitrogen content in different soil size fractions of a North Florida Spodosol", Plant and soil. Springer, 294(1), pp. 291303.

85. Schmidt, M. W. I. et al. (1999). "Charred organic carbon in German chernozemic soils", European Journal of Soil Science. Wiley Online Library, 50(2), pp. 351-365.

86. Schmidt, M. W. I. et al. (2001). "Comparative analysis of black carbon in soils", Global biogeochemical cycles. Wiley Online Library, 15(1), pp. 163-167.

87. Schmidt, M. W. I., Skjemstad, J. O. and Jäger, C. (2002). "Carbon isotope geochemistry and nanomorphology of soil black carbon: Black chernozemic soils in central Europe originate from ancient biomass burning", Global Biogeochemical Cycles. Wiley Online Library, 16(4), pp. 70-71.

88. Schnitzer, M. (1978). "Humic substances: chemistry and reactions", in Developments in soil science. Elsevier, pp. $1-64$.

89. Schulten, H.-R. and Schnitzer, M. (1993). "A state of the art structural concept for humic substances", Naturwissenschaften, 80(1), pp. 29-30.

90. Senesi, N. et al. (2007). "A comparative survey of recent results on humic-like fractions in organic amendments and effects on native soil humic substances", Soil biology and biochemistry. Elsevier, 39(6), pp. 1244-1262.

91. Senesi, N., Miano, T. M. and Brunetti, G. (1994). "Methods and related problems for sampling soil and sediment organic matter. Extraction, fractionation and 
purification of humic substances", QUIMICA ANALITICA-BELLATERRA- EDICIONES UNIVERSIDAD DE SALAMANCA, 13, pp. S26-S26.

92. Senesi, N., Saiz-Jiminez, C. and Miano, T. M. (1992). "Spectroscopic characterization of metal-humic acid-like complexes of earthworm-composted organic wastes", Science of the total Environment. Elsevier, 117, pp. 111-120.

93. Senesi, N., Testini, C. and Miano, T. M. (1987). "Interaction mechanisms between humic acids of different origin and nature and electron donor herbicides: a comparative IR and ESR study", Organic geochemistry. Elsevier, 11(1), pp. 25-30.

94. Seyedbagheri, M.-M. (2010). "Influence of humic products on soil health and potato production", Potato Research. Springer, 53(4), pp. 341-349.

95. Sherwood, P. (1993). "Soil stabilization with cement and lime".

96. Shi, Y. et al. (2001). "Surface amendments to minimize ammonia emissions from beef cattle feedlots", Transactions of the ASAE. American Society of Agricultural and Biological Engineers, 44(3), p. 677.

97. Shindo, H. (1990). "Catalytic synthesis of humic acids from phenolic compounds by Mn (IV) oxide (birnessite)", Soil science and plant nutrition. Taylor \& Francis, 36(4), pp. 679-682.

98. Simpson, M. J. and Hatcher, P. G. (2004). "Overestimates of black carbon in soils and sediments", Naturwissenschaften. Springer, 91(9), pp. 436-440.

99. Skjemstad, J. O. et al. (1996). "The chemistry and nature of protected carbon in soil", Soil Research. CSIRO, 34(2), pp. 251-271.

100. Skjemstad, J. O. et al. (2002). "Charcoal carbon in US agricultural soils", Soil Science Society of America Journal.
Wiley Online Library, 66(4), pp. 12491255.

101. Skjernstad, J. O., Taylor, J. A. and Smernik, R. J. (1999). "Estimation of charcoal (char) in soils", Communications in Soil Science and Plant Analysis. Taylor \& Francis, 30(15-16), pp. 2283-2298.

102. Steelink, C. (2002). "Peer reviewed: investigating humic acids in soils", ACS Publications.

103. Steinberg, C. (2003). "Ecology of humic substances in freshwaters: determinants from geochemistry to ecological niche", Springer Science \& Business Media.

104. Stevenson, F. J. (1994). "Humus chemistry: genesis, composition, reaction", John Wiley \& Sons.

105. Stevenson, F. J. and He, X. (1990). "Nitrogen in humic substances as related to soil fertility", Humic substances in soil and crop sciences: Selected readings. Wiley Online Library, pp. 91-109.

106. Sylvia, D. M. et al. (2005). "Principles and applications of soil microbiology", Pearson.

107. Tejada, M. and Gonzalez, J. L. (2008). "Influence of two organic amendments on the soil physical properties, soil losses, sediments and runoff water quality", Geoderma. Elsevier, 145(3-4), pp. 325334.

108. Thorn, K. A. and Mikita, M. A. (2000). "Nitrite fixation by humic substances nitrogen-15 nuclear magnetic resonance evidence for potential intermediates in chemodenitrification", Soil Science Society of America Journal. Wiley Online Library, 64(2), pp. 568-582.

109. Urrutia, O. et al. (2014). "Physicochemical characterization of humic-metalphosphate complexes and their potential application to the manufacture of new types of phosphate-based fertilizers", 
Journal of Plant Nutrition and Soil Science. Wiley Online Library, 177(2), pp. $128-136$.

110. Varanini, Z. and Pinton, R. (2006). "Plant-soil relationship: role of humic substances in iron nutrition", in Iron nutrition in plants and rhizospheric microorganisms. Springer, pp. 153-168.

111. Vaughan, D. and Ord, B. G. (1985). "Introduction soil organic Matter-a perspective on its nature, extraction, turnover and role in soil fertility", in Soil organic matter and biological activity. Springer, pp. 1-35.

112. Wang, M. C. and Huang, P. M. (1987). "Catalytic polymerization of hydroquinone by nontronite", Canadian journal of soil science. NRC Research Press Ottawa, Canada, 67(4), pp. 867-875.

113. Wang, T. S. C., Li, S. W. and Ferng, Y. L. (1978). "Catalytic polymerization of phenolic compounds by clay minerals", Soil Science. LWW, 126(1), pp. 15-21.

114. Weichelt, T. (1977). "Chemical alterations of natural lignin by interactions with humic like autoxidation products of pyrogallol (1, 2, 3 trihydroxybenzene)", in Soil Organic Matter Studies; Proceedings of a Symposium.

115. Wershaw, R. L. (2000). "The study of humic substances--In search of a paradigm".

116. Zech, W. et al. (1997). "Factors controlling humification and mineralization of soil organic matter in the tropics", Geoderma. Elsevier, 79(1-4), pp. 117-161.

117. Zhang, G. S. et al. (2007). "Relationship between soil structure and runoff/soil loss after 24 years of conservation tillage", Soil and Tillage Research. Elsevier, 92(12), pp. 122-128.
118. Ziechmann, W. (1960). "Über Modellreaktionen zur Bildung synthetischer Huminsäuren. 2. Die Synthese von Huminsäuren im neutralen Milieu", Brennstoffchem, 41, pp. 334-340. 119. Ziechmann, W. H. (1980). "Verlag Chemie", Weinheim, Germany. 